\title{
DETOXIFICATION OF TOXIC METAL IONS BY SORPTION ONTO ACTIVATED CARBON FROM HEVEA BRASILIENSIS BARK - A COMPARATIVE STUDY
}

\author{
N. KANNAN ${ }^{1, *}$ \\ T. VEEMARAJ ${ }^{2}$
}

\author{
${ }^{1}$ Department of Chemistry (PG), \\ Ayya Nadar Janaki Ammal College (Autonomous), \\ Sivakasi-626 124, Tamil Nadu, India. \\ ${ }^{2}$ UGC-JRF, Department of Chemistry (PG), \\ Ayya Nadar Janaki Ammal College (Autonomous), \\ Sivakasi-626 124, Tamil Nadu, India.
}

Received: 09/08/09

Accepted: 05/02/10 *to whom all correspondence should be addressed: e-mail: vgr_anjac@sancharnet.in

\begin{abstract}
Sorption of toxic metal ions $\left(\mathrm{Ni}^{2+}, \mathrm{Cu}^{2+}\right.$ and $\left.\mathrm{Cd}^{2+}\right)$ from Hevea brasiliensis bark carbon (HBBC) was carried out at $30 \pm 1{ }^{\circ} \mathrm{C}$ under various experimental conditions. Effect of various process parameters has been investigated by following the batch adsorption technique at $30 \pm 1^{\circ} \mathrm{C}$. The percentage removal increased with decrease in initial concentration and particle size and increase in contact time and dose of adsorbent. As initial $\mathrm{pH}$ of the slurry increased, the percentage removal increased, reached a maximum. The adsorption is highly $\mathrm{pH}$ sensitive. Adsorption data were modelled with various isotherms and first order kinetic equations proposed by Natarajan-Khalaf, Lagergren and Bhattacharya-Venkobachar and intraparticle diffusion models found to be applicable. Kinetics of adsorption is observed to be first order with Intra- particle diffusion as one of the rate determining steps. The monolayer adsorption capacities of HBBC also studied by Langmuir isotherms. HBBC could be used as low-cost adsorbents in effluent treatment, especially for the removal of metal ions, particular in $\mathrm{Ni}^{2+}, \mathrm{Cu}^{2+}$ and $\mathrm{Cd}^{2+}$ ions. It is confirmed by FT-IR studies before and after adsorption.
\end{abstract}

KEYWORDS: Toxic metal ions, Hevea brasiliensis bark carbon, adsorption, kinetic equations, intraparticle diffusion.

\section{INTRODUCTION}

As a modern world, the increase of industrial activities has intensified environmental pollution problems and the deterioration of several ecosystems with the accumulation of pollutants, especially heavy metals. Effluents containing heavy metals are discharged from various industrial processes. According to World Health Organization (WHO) the metals of the most immediate concern are copper, cadmium, nickel, mercury, lead, chromium, manganese, zinc and aluminium. All toxic metal ions (Nickel, copper and cadmium) have received a great deal of attention. These metals may be found in wastewater discharges from the plating industry, the manufacture of cadmium-nickel batteries, fertilizers, pesticides, lead mining, pigments dyes and textile operations (Salim et al., 1992; Grayson and Othumer, 1978). The major ill-effects caused by metal ions are erythrocyte destruction, dermatitis, inhibition of enzyme activity, head ache, Wilkinson disease, dizziness, nausea and vomiting, chest pain, tightness of chest, dry cough, shortness of breath, rapid respiration, nephritis, cyanosis and extreme weakness. The use of activated carbon for the removal of the toxic metal ionic pollutants present in low concentration in aqueous solution is of considerable importance. Activated Carbon ( $A C)$ adsorption is being widely used in effluent treatment. Because of high cost of commercial $A C$ (CAC) and difficulty in its procurement low-cost adsorbents alternative to CAC are to be developed from abundant agricultural wastes (Annadurai and Krishnan, 1996). This has necessitated the titled investigation to find out the suitability of Hevea brasiliensis bark carbon for the removal of toxic metal ions $\left(\mathrm{Ni}^{2+}, \mathrm{Cu}^{2+}\right.$ and $\left.\mathrm{Cd}^{2+}\right)$. The objectives of this study is to indigenously prepare AC (IPAC) from Hevea brasiliensis bark to study the effect of various process parameters 
on the extent of removal of these toxic metal ions and to model the adsorption data with various isotherms, first order kinetic equations and intra-particle diffusion model.

\section{MATERIAL AND METHOD Materials}

Hevea brasiliensis bark was carbonized with sodium bicarbonate at $300-400^{\circ} \mathrm{C}$ and kept at $600^{\circ} \mathrm{C}$ in a muffle furnace (Neolab, India) to get carbon. The carbon was sieved (90, 125, 150, 180, 210, 250 micron), activated by acid digestion $\left(4 \mathrm{~N} \mathrm{HNO}_{3} ; 2 \mathrm{hr}\right.$ at $\left.80^{\circ} \mathrm{C}\right)$ and dried in an air - oven (at $120^{\circ} \mathrm{C}$ for 2hr). Batch type adsorption studies were carried out (Kadirvelu and Namasivayam, 2003) under various experimental conditions. Nickel ammonium sulphate (AR), Cupric sulphate (AR) and Cadmium nitrate (AR) were suitably diluted individually with deionised water and estimated by sodium salt of ethylenediaminetetraacetic acid (EDTA) using murexide, Fast Sulphon Black-F and xylenol orange. Adsorption experiments were carried out at room temperature $\left(30 \pm 1^{\circ} \mathrm{C}\right)$ under batch mode (Kannan, 1991). Toxic metal $\left(\mathrm{Ni}^{2+}, \mathrm{Cu}^{2+}\right.$ and $\left.\mathrm{Cd}^{2+}\right)$ ions concentration were estimated complexometric titration as per the literature methods (Jeffery et al., 1991). Effect of various process parameters on the extent of removal of toxic metal ions was studied. The data were analysed statistically and interpreted.

\section{Adsorption experiments}

Adsorption experiments were carried out at room temperature $\left(30+1^{\circ} \mathrm{C}\right)$ under batch mode. Stock solution of metal salts (AR) were prepared suitably diluted with $\bar{D}$ water and estimated by EDTA method using (Jeffery et al., 1991) indicators. Exactly $50 \mathrm{~mL}$ of metal ion solution of known initial concentration was shaken with a required dose of adsorbent $\left(\mathrm{HBBC}=2-20 \mathrm{~g} \mathrm{~L}^{-1}\right)$ of a fixed particle size (HBBC=90-250 micron) in a thermostatic orbit incubator shaker (Neolab, India) at $200 \mathrm{rpm}$ after noting down the initial $\mathrm{pH}$ of the solution $\left(\mathrm{pH}=6.1\right.$ for $\mathrm{Ni}^{2+} ; 7$ for $\mathrm{Cu}^{2+}$ and $\left.\mathrm{Cd}^{2+}\right)$. The initial $\mathrm{pH}$ was adjusted to the required $\mathrm{pH}$ value (range: 2-10) by adding either $1 \mathrm{M} \mathrm{HCl}$ or $1 \mathrm{M} \mathrm{NaOH}$ solution. After equilibration, the final concentrations $\left(C_{e}\right)$ were also estimated complexometrically (Jeffery et al., 1991). The value of percentage removal and amount adsorbed (Kannan and Rajakumar, 2003) were calculated using the following relationships:

Percentage removal $=100\left(C_{i}-C_{e}\right) / C_{i}$

Amount adsorbed $(q)=\left(C_{i}-C_{e}\right) / m$

where, $C_{i}$ and $C_{e}$ are initial and equilibrium (final) concentration of toxic metal ions (ppm), respectively and $\mathrm{m}$ is the mass of adsorbent, in $\mathrm{g} \mathrm{L}^{-1}$.

FT-IR spectra were recorded as KBr pellets utilizing a SHIMADZU FT-IR 410 spectrometer.

\section{RESULTS AND DISCUSSION}

\section{Instrumentation techniques}

FT-IR spectra were recorded for the $\mathrm{AC}$ samples with and without $\mathrm{Ni}^{2+}, \mathrm{Cu}^{2+}$ and $\mathrm{Cd}^{2+}$ loading. The characteristic group frequencies $\left(\bar{v}\right.$, in $\left.\mathrm{cm}^{-1}\right)$ observed for various surface functional groups are shown in Table 1. The FT-IR spectra of various carbons and metal ion-loaded HBBC are almost similar with slight shift in frequencies (Sharma, 1980).

The surface functional groups are almost common as revealed by some common peaks, which appeared at 3412-3461, 2829-2945, 1612-1821, 1430-1576, 615-687 and 1240-1504 $\mathrm{cm}^{-1}$; depending upon the nature and type of raw materials. The characteristic peaks are slightly varying in their position for different IPAC. A peak around 1800-1600 $\mathrm{cm}^{-1}$ in HBBC confirms the presence of carbonyl group. This was further evidenced by another peak around $1650-1675 \mathrm{~cm}^{-1}$, which reveals the keto nature. The peak around $3400-3550 \mathrm{~cm}^{-1}$ confirms the presence of $-\mathrm{OH}$ group. The functional groups may be $-\mathrm{COOH}$ and/or $-\mathrm{OH}$. The IR peaks around $1200-1500 \mathrm{~cm}^{-1}$ may be due to the stretching vibrations of lactone $\left(\gamma\right.$ and $/$ or $\delta$ ), $=\mathrm{C}-\mathrm{O},-\mathrm{CH}=$ and $-\mathrm{CH}_{2}$ - functional groups. The IR spectra indicate the presence of surface functional groups like $\mathrm{C}=\mathrm{O},-\mathrm{COOH},-\mathrm{OH},-\mathrm{CO}-\mathrm{O}-\mathrm{CO}-,-\mathrm{C}$ $\mathrm{O}-\mathrm{C}-$, etc., and their involvement in the adsorption process. 
Table 1. FT-IR Spectroscopic characteristic frequencies $\left(\bar{v}\right.$ in $\left.\mathrm{cm}^{-1}\right)$ of $^{\mathrm{Ni}^{2+}}, \mathrm{Cu}^{2+}$ and $\mathrm{Cd}^{2+}$ onto HBBC - before and after adsorption of Toxic metal ions*

$\mid$\begin{tabular}{|l|c|c|c|}
\hline \multicolumn{1}{|c|}{ Assignment } & $\mathbf{N i}^{2+}$ & $\mathbf{C u}^{2+}$ & $\mathbf{C d}^{2+}$ \\
\hline O-H stretching & 3402 & 3411 & 3410 \\
& $*(3350)$ & $(3351)$ & $(3448)$ \\
\hline C-H stretching & 2922 & 2934 & 2941 \\
& $(2818)$ & $(2915)$ & $(2833)$ \\
\hline C=O stretching & 1715 & 1611 & 1655 \\
& $(1712)$ & $(1609)$ & $(1623)$ \\
\hline $\mathrm{CH}_{2}$ bending & 1461 & 1535 & 1422 \\
& $(1412)$ & $(1498)$ & $(1418)$ \\
\hline C-S stretching & 605 & 636 & 610 \\
& $(679)$ & $(656)$ & $(626)$ \\
\hline C-O-C stretching & 1033 & 1004 & 1021 \\
& $(1052)$ & $(1041)$ & $(1031)$ \\
\hline
\end{tabular}
*Values in parentheses are for $\mathrm{Ni}^{2+}, \mathrm{Cu}^{2+}$ and $\mathrm{Cd}^{2+}$ ions-loaded carbon.

\section{Effect of Process parameters}

The adsorption experiments were carried out at different experimental conditions (Table 2) and the results obtained are discussed below:

\section{Effect of initial concentration}

The results on the extent of removal of toxic metal ions under various experimental conditions are given in Table 2. The percentage removal ( $\% \mathrm{R})$ decreased with increase in initial concentration, due to the limited number of available active sites on the surface of HBBC to accommodate higher concentration of toxic metal ions $\left(\mathrm{Ni}^{2+}, \mathrm{Cu}^{2+}\right.$ and $\left.\mathrm{Cd}^{2+}\right)$ (Kannan and Rajakumar, 2003). The effect of initial concentration is shown in Figure 1.

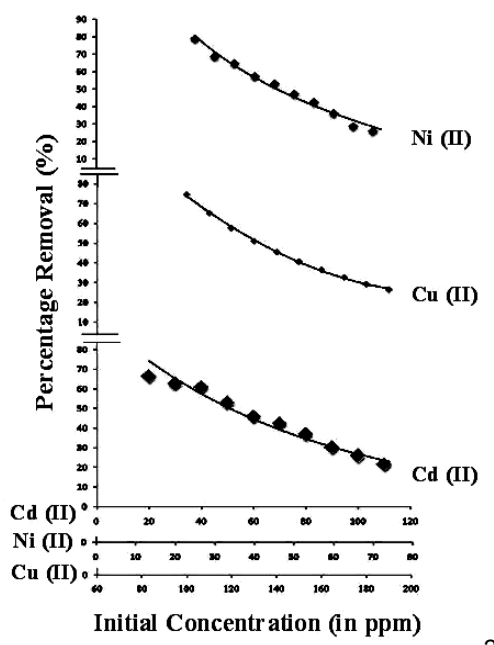

Figure 1. Effect of initial concentration for the removal of $\mathrm{Ni}^{2+}, \mathrm{Cu}^{2+}$ and $\mathrm{Cd}^{2+}$ onto $\mathrm{HBBC}$

\section{Adsorption isotherms}

Adsorption data were fitted with Freundlich and Langmuir isotherms (Kannan and Rajakumar, 2003) by carrying out the correlation analysis. The results are given in Table 3 . The observed $r$-values close to unity indicate the applicability of these two isotherms. HBBC, as evidenced from $Q_{0}$ (monolayer adsorption capacity, in $\mathrm{mg} \mathrm{g}^{-1}$ ) values.

Freundlich isotherm: $\log q=\log K+(1 / n) \log C_{e}$

Langmuir isotherm : $\left(C_{e} / q\right)=\left(1 / Q_{0} b\right)+\left(C_{e} / Q_{o}\right)$

where, $\mathrm{K}$ and $1 / \mathrm{n}$ are the measures of adsorption capacity and intensity of adsorption, respectively; $\mathrm{q}$ is the amount adsorbed per unit mass of adsorbent (in $\mathrm{mg} \mathrm{g}^{-1}$ ); $\mathrm{Q}_{0}$ and $\mathrm{b}$ are Langmuir constants, 
which are the measures of monolayer adsorption capacity (in $\left.\mathrm{mg} \mathrm{g}^{-1}\right)$ and surface energy $\left(\mathrm{mg} \mathrm{L}^{-1}\right)$, respectively.

Table 2. Effect of initial concentration for the extent of removal of $\mathrm{Ni}^{2+}, \mathrm{Cu}^{2+}$ and $\mathrm{Cd}^{2+}$ onto $\quad \mathrm{HBBC}$ at $30 \pm 1^{\circ} \mathrm{C}$

\begin{tabular}{|l|c|c|c|c|}
\hline \multirow{2}{*}{ Process Parameter } & \multirow{2}{*}{ Range } & \multicolumn{3}{|c|}{ Percentage Removal } \\
\cline { 3 - 5 } & & $\mathbf{N i}^{2+}$ & $\mathbf{C u}^{2+}$ & $\mathbf{C d}^{2+}$ \\
\hline Initial conc. $(\mathrm{ppm})$ & $25-70\left(\mathrm{Ni}^{2+}\right)$ & $79-26$ & $75-26$ & $66-21$ \\
& $100-190\left(\mathrm{Cu}^{2+}\right)$ & $*(1.6-1.5)$ & $(6.2-4.2)$ & $(1.1-2.0)$ \\
& $20-110\left(\mathrm{Cd}^{2+}\right)$ & & & $13-40$ \\
Contact time $(\mathrm{min})$ & $5-55$ & $19-58$ & $12-60$ \\
& & $(0.8-2.4)$ & $(1.7-5.4)$ & $(0.7-3.5)$ \\
\hline Dose $\left(\mathrm{g} \mathrm{L}^{-1}\right)$ & $2-20$ & $30-74$ & $17-56$ & $28-60$ \\
& & $(1.2-3.1)$ & $(2.2-7.5)$ & $(1.6-3.5)$ \\
\hline Initial pH & $2-10$ & $26-72$ & $25-60$ & $20-82$ \\
& & $(1.1-3.0)$ & $(3.3-8.0)$ & $(1.2-4.8)$ \\
\hline Particle size $(\mu \mathrm{m})$ & $90-250$ & $58-11$ & $40-9$ & $60-23$ \\
& & $(2.4-0.5)$ & $(5.4-1.2)$ & $(3.5-1.3)$ \\
\hline
\end{tabular}

*Values in parentheses are amount adsorbed for $\mathrm{Ni}^{2+}, \mathrm{Cu}^{2+}$ and $\mathrm{Cd}^{2+}$ ions.

Table 3. Adsorption isotherm data for removal of $\mathrm{Ni}^{2+}, \mathrm{Cu}^{2+}$ and $\mathrm{Cd}^{2+}$ onto $\mathrm{HBBC}$ at $30 \pm 1{ }^{\circ} \mathrm{C}$

\begin{tabular}{|l|c|c|c|}
\hline \multirow{2}{*}{ Model Parameter } & \multicolumn{3}{|c|}{ Toxic metal ions } \\
\cline { 2 - 4 } & $\mathbf{N i}^{2+}$ & $\mathbf{C u}^{2+}$ & $\mathbf{C d}^{2+}$ \\
\hline Freundlich isotherm & & & \\
slope $(1 / \mathrm{n})$ & 0.108 & 1.050 & 0.381 \\
Intercept (log K) & 0.143 & 0.175 & 0.216 \\
$\mathrm{r}-$ value & 0.920 & 0.973 & 0.943 \\
$\Delta \mathrm{q}(\%)$ & 0.031 & 0.016 & 0.358 \\
\hline Langmuir isotherm & & & \\
Slope $\left(1 / \mathrm{Q}_{\mathrm{o}}\right)$ & 0.488 & 0.220 & 0.335 \\
Intercept $\left(1 / \mathrm{Q}_{\mathrm{o}} \mathrm{b}\right)$ & 0.625 & 2.047 & 3.207 \\
$\mathrm{r}-$ value & 0.999 & 0.997 & 0.996 \\
$\mathrm{Q}_{\mathrm{o}}\left(\mathrm{mg} \mathrm{g} \mathrm{g}^{-1}\right)$ & 2.051 & 4.546 & 2.981 \\
$\mathrm{~b}\left(\mathrm{~g} \mathrm{\textrm {L } ^ { - 1 }}\right)$ & 0.780 & 0.107 & 0.105 \\
$\mathrm{R}_{\mathrm{L}}$ value & 0.033 & 0.079 & 0.183 \\
$\Delta \mathrm{q}(\%)$ & 0.025 & 0.174 & 0.147 \\
\hline
\end{tabular}

In order to compare the validity of each model (isotherm) more efficiently a normalised standard deviation, $\Delta \mathrm{q}(\%)$ is calculated using the following equation:

$\Delta q(\%)=100 \times\left\{\left(\sum\left[\left(q_{t}^{\text {exp. }}-q_{t}^{\text {cal. }}\right) / q_{t}^{\text {exp. }}\right]^{2}\right) /(n-1)\right\}^{1 / 2}$

where, the superscripts, exp. and cal. are the experimental and calculated values of $q_{t}$ viz., the amount adsorbed at different time $t$ and $n$ is the number of observations. The $\Delta q(\%)$ values are also given in Table 3. Based on the low values of $\Delta q(\%)$, it is concluded that the adsorption of toxic metal ions can be best described by the Langmuir adsorption isotherm. The monolayer adsorption capacities $\left(Q_{0}\right)$ of the adsorbents are found to be of the order given below:

$$
\mathrm{Cu}^{2+}>>\mathrm{Cd}^{2+}>\mathrm{Ni}^{2+}
$$

Further, the essential characteristics of the Langmuir isotherm can be described by a Separation factor, $\mathbf{R}_{\mathbf{L}}$, which is defined by the following equation:

$\mathrm{R}_{\mathrm{L}}=\left[1 /\left(1+\mathrm{bC}_{\mathrm{i}}\right)\right]$

where, $\mathrm{C}_{\mathrm{i}}=$ optimum initial concentration of $\mathrm{Ni}^{2+}, \mathrm{Cu}^{2+}$ and $\mathrm{Cd}^{2+}$ ions (in $\mathrm{mg} \mathrm{L}^{-1}$ ) $\mathrm{b}=$ Langmuir constant (in $\mathrm{L} \mathrm{mg}^{-1}$ ) 
The values of separation factor, $R_{L}$ indicate the nature of the adsorption process as given below:

$$
\begin{aligned}
& \frac{R_{L}}{R_{L}}>1 \\
& R_{L}=1 \\
& 0<R_{L}<1 \\
& R_{L}=0
\end{aligned}
$$

Nature of adsorption process

Unfavourable

Linear

Favourable

Irreversible

In the present study, the computed values of $R_{\mathrm{L}}$ (Table 2 ) are found to be fraction in the range of $0-1$ $\left(0.033\right.$ for $\mathrm{Ni}^{2+}, 0.079$ for $\mathrm{Cu}^{2+}$ and 0.183 for $\mathrm{Cd}^{2+}$ ions), indicating that the adsorption process is favorable for this adsorbent (HBBC) for the removal of toxic metal ions.

\section{Effect of contact time}

The \% R increases with increase in contact time $\left(40 \mathrm{~min}\right.$., for $\mathrm{Ni}^{2+} ; 35 \mathrm{~min}$., for $\mathrm{Cu}^{2+}$ and $\mathrm{Cd}^{2+}$ ) due to more amounts of $\mathrm{Ni}^{2+}, \mathrm{Cu}^{2+}$ and $\mathrm{Cd}^{2+}$ ions removed due to effective contact and due to the availability of active sites. The effect of contact time is shown in Figure 2. At the initial stage, the rate of removal of toxic metal ions was higher, due to the availability of more than the required number of active sites on the surface of carbons and became slower at the later stages of contact time, due to the decreased or lesser number of active sites. Similar results have been reported in literature for the removal of dyes (Kannan and Meenakshi Sundaram, 2002), organic acids and metal ions (Kannan and Veemaraj, 2009) by various adsorbents.

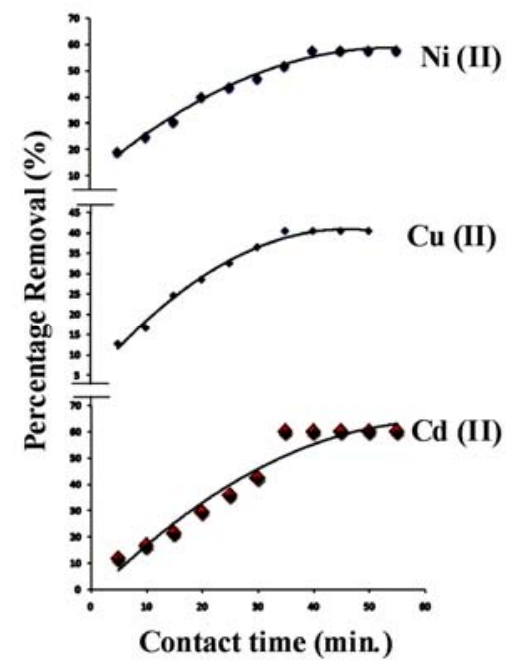

Figure 2. Effect of contact time for the removal of $\mathrm{Ni}^{2+}, \mathrm{Cu}^{2+}$ and $\mathrm{Cd}^{2+}$ onto $\mathrm{HBBC}$

\section{Kinetics of adsorption}

The first order kinetic equations like Natarajan-Khalaf (Raji et al., 1986), Lagergren (Lagergren, 1898) and Bhattacharya-Venkobachar (Bhattacharya and Venkobachar, 1984) equations were applied to the adsorption data (Table 4).

Natarajan and Khalaf equation:

Lagergren equation:

Bhattacharya and Venkobachar equation:

$$
\begin{aligned}
& \log \left(C_{i} / C_{t}\right)=(k / 2.303) t \\
& \log \left(q_{e}-q_{t}\right)=\log q_{e}-(k / 2.303) t \\
& \log [1-U(T)]=-(k / 2.303) t
\end{aligned}
$$

where,

$\mathrm{C}_{\mathrm{i}}$ and $\mathrm{C}_{\mathrm{t}}=$ concentration of $\mathrm{Ni}^{2+}, \mathrm{Cu}^{2+}$ and $\mathrm{Cd}^{2+}$ ions at time zero and time $\mathrm{t}$, respectively (in $\mathrm{mg} \mathrm{L}^{-1}$ ) $\mathrm{q}_{\mathrm{e}}$ and $\mathrm{q}_{\mathrm{t}}=$ amount of $\mathrm{Ni}^{2+}, \mathrm{Cu}^{2+}$ and $\mathrm{Cd}^{2+}$ ions adsorbed at equilibrium time and time $\mathrm{t}$, respectively (in $\mathrm{mg} \mathrm{g}^{-1}$ )

$\mathrm{U}(\mathrm{T}) \quad=\left[\left(\mathrm{C}_{\mathrm{i}}-\mathrm{C}_{\mathrm{t}}\right) /\left(\mathrm{C}_{\mathrm{i}}-\mathrm{C}_{\mathrm{e}}\right)\right]$

$\mathrm{C}_{\mathrm{e}} \quad=$ equilibrium $\mathrm{Ni}^{2+}, \mathrm{Cu}^{2+}$ and $\mathrm{Cd}^{2+}$ ions concentration (in $\mathrm{mg} \mathrm{L}^{-1}$ )

$\mathrm{k}=$ first order adsorption rate constant (in $\min ^{-1}$ ) 
The r-values (correlation coefficient close to unity) indicate the applicability of these kinetic equations and the first order nature of adsorption of $\mathrm{Ni}^{2+}, \mathrm{Cu}^{2+}$ and $\mathrm{Cd}^{2+}$ ions on HBBC. The rate of adsorption of $\mathrm{Ni}^{2+}, \mathrm{Cu}^{2+}$ and $\mathrm{Cd}^{2+}$ ions is calculated. The presence of intra- particle diffusion as the rate limiting step was tested by applying the intra- particle diffusion model.

$q_{t}=k_{p} t^{1 / 2}+c$

The higher value of $\mathrm{k}_{\mathrm{p}}\left(\mathrm{k}_{\mathrm{p}}\right.$ values $\left.=\mathrm{Ni}^{2+}=0.385 ; \mathrm{Cu}^{2+}=1.033 ; \mathrm{Cd}^{2+}=0.702\right)$ indicate that $\mathrm{HBBC}$ are highly porous in nature. The value of intercept (c) give an idea about the boundary layer thickness, i.e., larger the intercept $\left(\mathrm{Ni}^{2+}>\mathrm{Cu}^{2+}>\mathrm{Cd}^{2+}\right)$, greater is the boundary layer effect (Rajakumar, 2002).

Table 4. Kinetics of adsorption for removal of $\mathrm{Ni}^{2+}, \mathrm{Cu}^{2+}$ and $\mathrm{Cd}^{2+}$ onto $\mathrm{HBBC}$ at $30 \pm 1{ }^{\circ} \mathrm{C}$

\begin{tabular}{|c|c|c|c|}
\hline Model Parameter & $\mathrm{Ni}^{2+}$ & $\mathrm{Cu}^{2+}$ & $\mathrm{Cd}^{2+}$ \\
\hline $\begin{array}{l}\text { Natarajan-Khalaf eqn. } \\
10^{2} k\left(\text { min }^{-1}\right) \\
r-\text { value } \\
\Delta \mathrm{q}(\%)\end{array}$ & $\begin{array}{l}0.018 \\
0.995 \\
9.270 \\
\end{array}$ & $\begin{array}{l}0.013 \\
0.997 \\
7.517 \\
\end{array}$ & $\begin{array}{l}0.024 \\
0.942 \\
5.268 \\
\end{array}$ \\
\hline $\begin{array}{l}\text { Lagergren eqn. } \\
10^{2} k\left(\text { min. }^{-1}\right) \\
r-\text { value } \\
\Delta \mathrm{q}(\%)\end{array}$ & $\begin{array}{l}0.051 \\
0.972 \\
1.817 \\
\end{array}$ & $\begin{array}{l}0.059 \\
0.987 \\
0.699 \\
\end{array}$ & $\begin{array}{l}0.030 \\
0.980 \\
1.610 \\
\end{array}$ \\
\hline $\begin{array}{l}\text { Bhattacharya-Venkobachar eqn. } \\
10^{2} k\left(\text { min. }^{-1}\right) \\
r-\text { value } \\
\Delta \mathrm{q}(\%)\end{array}$ & $\begin{array}{c}0.051 \\
0.972 \\
21.694 \\
\end{array}$ & $\begin{array}{c}0.059 \\
0.987 \\
18.791\end{array}$ & $\begin{array}{c}0.030 \\
0.980 \\
33.460\end{array}$ \\
\hline $\begin{array}{l}\text { Intra-particle diffusion model } \\
k_{p}\left(\mathrm{mg} \mathrm{g}^{-1} \min ^{-1 / 2} .\right) \\
\text { Intercept }(c) \\
r-\text { value } \\
\Delta \mathrm{q}(\%)\end{array}$ & $\begin{array}{l}0.385 \\
0.127 \\
0.994 \\
0.241\end{array}$ & $\begin{array}{l}1.033 \\
0.799 \\
0.995 \\
0.404 \\
\end{array}$ & $\begin{array}{l}0.702 \\
1.216 \\
0.945 \\
4.873 \\
\end{array}$ \\
\hline $\begin{array}{l}\text { Log }(\% R) \text { vs Log(time) } \\
\text { slope } \\
r-\text { value } \\
\Delta q(\%)\end{array}$ & $\begin{array}{c}0.535 \\
0.993 \\
38.358\end{array}$ & $\begin{array}{c}0.619 \\
0.993 \\
56.997\end{array}$ & $\begin{array}{c}0.806 \\
0.975 \\
45.003\end{array}$ \\
\hline
\end{tabular}

The values of $\log (\% \mathrm{R})$ are found to be linearly correlated $\left(r\right.$ values $\mathrm{Ni}^{2+}=0.993 ; \mathrm{Cu}^{2+}=0.993$ and $\mathrm{Cd}^{2+}=0.975$ ) with log (time), with slope values are greater than 0.5 (slope: $\mathrm{Ni}^{2+}=0.535 ; \mathrm{Cu}^{2+}=0.619$ and $\mathrm{Cd}^{2+}=0.806$ ). This indicates that besides the intra- particle diffusion, there may be other processes controlling the rate of adsorption, all of which may be operating simultaneously. The results of the present study conclude that HBBC could be used as low-cost adsorbent in effluent treatment, especially for the removal of toxic metal ions.

\section{Effect of dose of adsorbent}

The $\% \mathrm{R}$ increased with increase in dose of adsorbent owing to the increase in surface area and number of active sites for the adsorption of $\mathrm{Ni}^{2+}, \mathrm{Cu}^{2+}$ and $\mathrm{Cd}^{2+}$ ions or due to the conglomeration of carbons at higher doses (Periasamy and Namasivayam, 1996; Kannan and Meenakshisundaram, 2002). The effect of dose is shown in Figure 3.

The relative increase in the percentage removal of toxic metal ions is found to be insignificant after a dose of $20 \mathrm{~g} \mathrm{~L}^{-1}$ of HBBC, which is fixed as the optimum dose. The values of log (\% R) are also found to be linearly correlated with log (dose) values. The values of $\log (\% R)$ are found to be linearly correlated to log (dose) with correlation coefficients, which are almost unity ( $r$ values $\mathrm{Ni}^{2+}=0.999 ; \mathrm{Cu}^{2+}=0.985$ and $\mathrm{Cd}^{2+}=0.935$ ).

This suggests that the adsorbed toxic metal ions $\left(\mathrm{Ni}^{2+}, \mathrm{Cu}^{2+}\right.$ and $\mathrm{Cd}^{2+}$ ions) may either block the access to the internal pores of carbons or may cause particles to aggregate and thereby minimizing 
the availability of active sites for adsorption (Periasamy and Namasivayam, 1996; Kannan and Veemaraj, 2009).

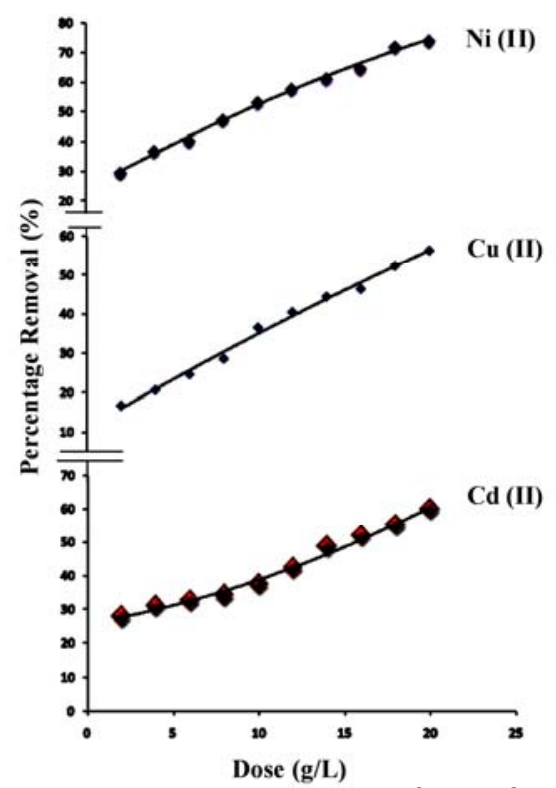

Figure 3. Effect of dose for the removal of $\mathrm{Ni}^{2+}, \mathrm{Cu}^{2+}$ and $\mathrm{Cd}^{2+}$ onto HBBC

\section{Effect of initial pH}

As initial $\mathrm{pH}$ increases, the extent of removal (\% R), increases reaches a maximum value (Kannan and Veemaraj, 2009). The effect of initial pH is shown in Figure 4. The optimum pH for removal of $\mathrm{Ni}^{2+}$ ions is fixed as 6.1 and $\mathrm{Cu}^{2+}$ and $\mathrm{Cd}^{2+}$ ions are fixed as 7.0. The near neutral $\mathrm{pH}$ is found to be favourable. The $\mathrm{pH}$ value slightly decreases and change in $\mathrm{pH}(\Delta \mathrm{pH}=$ initial $\mathrm{pH}$ - final $\mathrm{pH})$ values after adsorption are found to decrease in the order of 0.3-0.5 units (Kannan and Raja Kumar, 2003). This suggests that during the adsorption of nickel species, protons are released from the surface functional groups like phenolic, carboxylic and enolic groups present on the carbons.

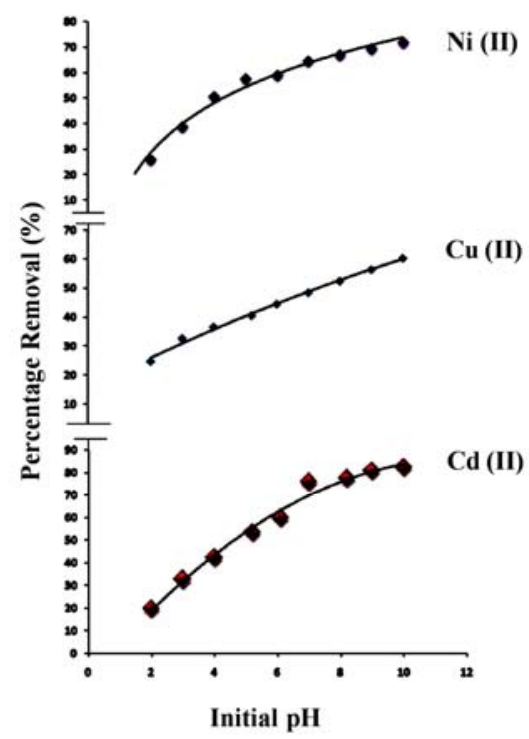

Figure 4. Effect of $\mathrm{pH}$ for the removal of $\mathrm{Ni}^{2+}, \mathrm{Cu}^{2+}$ and $\mathrm{Cd}^{2+}$ onto HBBC

\section{Effect of particle size}

The amount of toxic metal ions adsorbed increases with decrease in particle size of the adsorbent (Kannan and Rajakumar, 2003). The effect of particle size is shown in Figure 5. This is due to the availability of surface area with the decrease in particle size. 


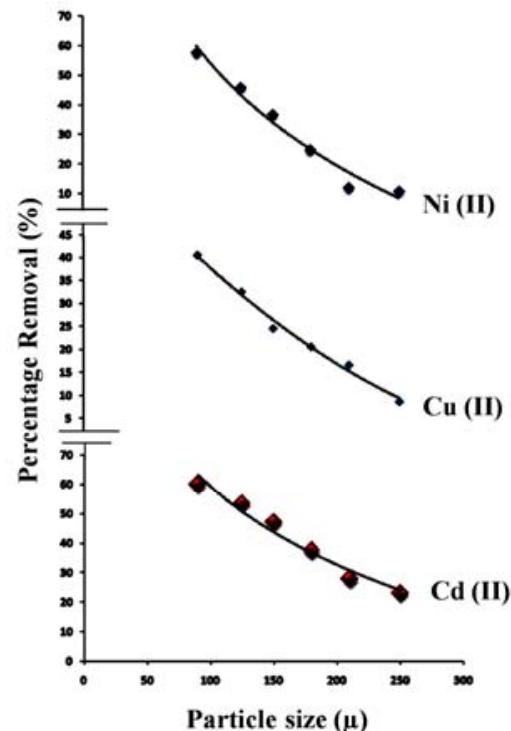

Figure 5. Effect of particle size for the removal of $\mathrm{Ni}^{2+}, \mathrm{Cu}^{2+}$ and $\mathrm{Cd}^{2+}$ onto $\mathrm{HBBC}$

The optimum conditions fixed for the effective removal of nickel (II) ions are: $\mathrm{C}_{\mathrm{i}}=25 \mathrm{ppm}$ for $\mathrm{Ni}^{2+}$; $100 \mathrm{ppm}$ for $\mathrm{Cu}^{2+}$ and $20 \mathrm{ppm}$ for $\mathrm{Cd}^{2+}$; contact time $=40 \mathrm{~min}$., for $\mathrm{Ni}^{2+} ; 35 \mathrm{~min}$., for $\mathrm{Cu}^{2+}$ and $\mathrm{Cd}^{2+}$; dose $=20 \mathrm{~g} \mathrm{~L}^{-1}$ for $\mathrm{Cd}^{2+}$ and $12 \mathrm{~g} \mathrm{~L}^{-1}$ for $\mathrm{Ni}^{2+}$ and $\mathrm{Cu}^{2+}$; particle size $=90$ micron and $\mathrm{pH}=6.1$ for $\mathrm{Ni}^{2+}$ and 7.0 for $\mathrm{Cu}^{2+}$ and $\mathrm{Cd}^{2+}$ at $200 \mathrm{rpm}$ speed and $30 \pm 1^{\circ} \mathrm{C}$.

\section{CONCLUSION}

Adsorbate species are found to adsorb strongly on the surface of HBBC. The faster adsorption kinetic data may be useful for environmental technologists in designing $\mathrm{Ni}^{2+}, \mathrm{Cu}^{2+}$ and $\mathrm{Cd}^{2+}$ containing waste water. The adsorption process is found to be first order with intra-particle diffusion as one of the rate determining steps. HBBC possess the maximum adsorption capacity and hence, it is an effective adsorbent for the removal of toxic metal ions like $\mathrm{Ni}^{2+}, \mathrm{Cu}^{2+}$ and $\mathrm{Cd}^{2+}, \mathrm{HBBC}$ could be considered as cost-effective adsorbent and useful for the economic treatment of waste water containing $\mathrm{Ni}^{2+}, \mathrm{Cu}^{2+}$ and $\mathrm{Cd}^{2+}$ to use an agricultural material Hevea brasiliensis bark as an adsorbents

\section{ACKNOWLEDGEMENT}

The authors thank the Management and Principal of ANJA College, Sivakasi, for providing facilities and encouragement. The authors also thank the UGC, New Delhi, for financial assistance under UGC-Major Research Project (UGC F. No. 33-306/2007(S.R.) dated 28.02.2008) scheme.

\section{REFERENCES}

1. Salim R., Al-Subu M.M. and Sahrhage E. (1992) Uptake of cadmium from water by beech leaves, J. Environ. Sci. Health, A27(3), 603-627.

2. Grayson M. and Othumer K. (1978) Encyclopedia of Chemical Technology, $43^{\text {rd }}$ ed., John Wiley \& Sons.

3. Annadurai G. and Krishnan M.R.V. (1996) Adsorption of basic dye using chitin, Indian J. Env. Prot., 16(6), 444-449.

4. Bhattacharya A.K. and Venkobachar C. (1984) Removal of cadmium by low cost adsorbent, J. Am. Civ. Engg., 110, 110-116.

5. Corapcioglu M.O. and Huang C.P. (1987) The adsorption of heavy metals onto hydrous activated carbon, Water Res., 21(9), 1031-1044.

6. Jeffery G.H., Bassett I., Mendham J. and Denney R.C., (Eds) (1991) Vogel's Text Book of Quantitative Chemical Analysis, ELBS, Longman, London, p. 689.

7. Kadirvelu K. and Namasivayam C. (2003) Activated carbon from coconut coirpith as metal adsorbent: adsorption of $\mathrm{Cd}(\mathrm{II})$ from aqueous solution, Advances in Environ. Res., 7, 471-478.

8. Kannan N. (1991) A study on removal of nickel by adsorption on flyash, Indian J. Env. Prot., 11(7), 514-518. 
9. Kannan N. and Meenakshisundaram M. (2002) Adsorption of congo red on various activated carbons-A comparative study, Water, Air, Soil Poll., 138, 289-305.

10. Kannan N. and Veemaraj T. (2009) Removal of lead (II) ions by adsorption onto bamboo dust and commercial activated carbons - A comparative study, E-Journal of Chemistry, 6(2), 247-256.

11. Kannan N. and Raja Kumar A. (2003) Suitability of various indigenously prepared activated carbons for the adsorption of mercury[II] ions, Toxicol.Env.Chem., 84(14), 7-19.

12. Kannan N. and Xavier A. (2001) New comparative mixed adsorbents for the removal of acetic acid by adsorption from aqueous solutions-A comparative study, Toxicol.Env. Chem., 19, 95-107.

13. Lagergren S. (1898). About the theory of so-called adsorption of soluble substances. K. Sven Vetenskapsakad. Handl., 24(4), 1-39.

14. Periasamy K. and Namasivayam C. (1996) Removal of copper (II) by adsorption onto peanut hull carbon from water and copper plating industry wastewater. Chemosphere, 32(4), 769-789.

15. Raji C., Manju G.N. and Anirudhan T.S. (1997) Removal of heavy metal ions from water using sawdust-based activated carbon, Indian J. Eng. Mater. Sci., 4(6), 254-260.

16. Rajakumar A. (2002). Kinetics of adsorption of heavy metals by activated carbons, Ph.D. thesis, Madurai Kamaraj University, Madurai.

17. Sharma Y.R. (1980) Elementary organic spectroscopy, S. Chand \& Company Limited, New Delhi. 